\title{
Impact of Water Resources Protection on Local Ground Water Market
}

\author{
Baskaran Anuradha ${ }^{1}$, Neelakanda Kannaperumal Ambujam ${ }^{2}$ \\ ${ }^{1}$ Department of Civil Engineering, Madha Engineering College, Chennai, India \\ ${ }^{2}$ Centre for Water Resources, Anna University, Chennai, India \\ E-mail: anu_bas2003@yahoo.com \\ Received May 27, 2010; revised July 5, 2010; accepted July 15, 2010
}

\begin{abstract}
Tanks are important means to conserve water resources in semi-arid areas. Tank irrigation in general, and in Tamil Nadu in particular, has a long history, and it can be traced to prehistoric times. Poor management of the integrated tank system including its structures and distribution system is one of the major reasons for decline of tank irrigated area. Rehabilitating tanks enhanced groundwater recharge leads to increased water table in the wells located in the command area. Hence well owning farmers can able to cultivate three times paddy crop in a year with the available ground water. Also they can provide water for adjacent non-well owning farmers for their second crop (during maturity stage) and third crop (whole season) cultivation by charging either cash or kind. This local ground water market helps villagers to cultivate more area and season, leads to efficient water use and increased income generation for the villagers. To prove the above statement a study was carried out in rural village of South India with an interview schedule and the data were analysed using SPSS (Statistical Package for Social Science). The result shows that the tank rehabilitation is highly correlated with local ground water market in post rehabilitation period.
\end{abstract}

Keywords: Agriculture, Groundwater Market, Tank Rehabilitation, Irrigation

\section{Introduction}

Localized village-level informal arrangement through which well owners sell irrigation services to other members of the community. Water may be lifted from open wells or tube wells, deep or shallow wells and may be transported to the buyers field either through lined or unlined field channels or through underground pipeline networks. According to [1], the emergence of water markets, both ground and surface water, has helped in increasing agricultural output. It has also widened the equalities in the rural areas and protected the interests of the small and marginal farmers and other weaker sections of the society. Where land holding are fragmented, most sellers of water are also buyers themselves. In areas irrigated through water markets, the intensity of irrigation may vary greatly. However, since the buyers can get water when they need, the productivity of water is high. Opportunity to buy small quantities of water at crucial periods of moisture stress enables small holders to take an additional crop. Water selling by private owners can have remarkable beneficial impacts on the incomes of water buyers and the economy of the community as a whole [2,3]. Some of the findings from [4] study in eastern and western Utter Pradesh about trends in ground water irrigation indicate that significant changes have taken place in respect of socio-economic features, role of ground water irrigation including ground water markets, productivity of crops and changing face of the rural elite. Marginal farmers are the biggest beneficiaries of ground water market. Nearly $60 \%$ of the farmers of this category irrigated their crop by water purchased from well owners making ground water accessible to socially and economically deprived sections of the society [5] Efficiency and equity benefits of ground water markets have an inadequate empirical grounding and are based on a 'one size fits all' model of water market that is insensitive to how ground water markets are shaped by natural, social and historical factors [6]. Performance of water market is in terms of the quality of irrigation service available for the depth and breadth of water trade, and the presence or absence of monopoly pricing. The impact of water market on cropping intensity, cropping pattern, labour use and crop yields achieved by water buyer compared to water extraction mechanism owners. When water is sold 
for cash, it may be priced on the basis of hectares (ha) irrigated of a particular crop or on the basis of hours of pumping [7].

Water markets emerging under the flat price power enable small farmers to gain access to water supplies at less than the full cost of pumping and infrastructure [8]. Due to operation on localised water markets, substantial proportion of the total benefit generated by private investment in water extraction mechanisms accrue to the resource poor non-water extraction mechanism owning farmers and even the landless. This proportion tends to increase as the water markets become more 'efficient' and the gap between the incremental pumping costs and water prices declines [9]. Ground water irrigation is a major source of livelihood not only for well owners, but also for water buyer and farm labourers [10].

\section{Materials and Methods}

This study was carried out in a rural village named 'Pelasur' of Thiruvannamalai district of Tamil Nadu, India. This tank was rehabilitated in the year 2001-2002 with World Bank funding of Rs. 40.01 lakhs. Twenty percent households of women and men farmers who owned atleast one irrigated plot of land under the 'Pelasur' tank command area were selected as respondents using Stratified sampling method. In order to achieve the proposed objectives, combination of quantitative and qualitative methods were used to gather information about local ground water market in pre and post rehabilitation period. Year of consideration for data collection were June 1998-May 1999 and June 2004-May 2005 for before and after rehabilitation respectively. The data thus obtained were first master tabled using appropriate coding and the variables for inclusion in analysis were selected and transmitted into raw data files. Further, it was arranged into SPSS-files for statistical analysis which in fact proved to be a cumbersome part of the research. Since this study concentrates on tank and well water users both before and after rehabilitation, comparative analysis in SPSS was attempted using paired-samples t-test, which is a compare means analysis.

\section{Results and Discussions}

Table 1 elucidates the prevalence of water marketing in different seasons and stages of crop growth in 'Pelasur'. Irrespective of the crop cultivation season, the general scenario of buying and selling water is practised in this village. However, it is evident from the data that during second season, total number of ground water buying and selling is increased in post rehabilitation period. But buying and selling is not done by the same respondents in pre and post rehabilitation period. With the help of tank water, farmers cultivate entire first season paddy crop and for second season they are depending on neighbouring well owning farmers. When tank water fails to full fill the needs, especially during flowering and maturity stages of paddy crop, some 4 to 5 watering from well will save crop from reduction in yield. It is estimated that out of 60 bags/ha (each bag weights about 75 $\mathrm{kg}$ ) only half the quantity will be received due to the above situation (i.e. 30 bags). Income realised through these 30 bags of paddy/ha is Rs. 15,000/-, which is considered to be very low. Hence, input and out put costs per ha are the same and there will not be any profit as claimed by the respondents. So, non-well owning farmers are ready to buy water from well owning farmers in order to avoid crop losses.

Mode of payments as claimed by well owners is either

Table 1. Season wise ground water buying and selling before and after rehabilitation by number of Pelasur respondents.

\begin{tabular}{|c|c|c|c|c|c|c|c|c|c|c|c|c|c|c|c|}
\hline \multirow{3}{*}{ S. No. } & \multirow{3}{*}{ Crop growth stage } & \multicolumn{6}{|c|}{$\begin{array}{l}\text { Number of Respondents } \\
\text { Ground water buying }\end{array}$} & \multicolumn{6}{|c|}{$\begin{array}{l}\text { Number of Respondent } \\
\text { Ground water selling }\end{array}$} & \multirow{3}{*}{$\mathbf{A}$} & \multirow{3}{*}{ B } \\
\hline & & \multicolumn{2}{|c|}{ Second season } & \multicolumn{2}{|c|}{ Third season } & \multicolumn{2}{|c|}{ Annual } & \multicolumn{2}{|c|}{ Second season } & \multicolumn{2}{|c|}{ Third season } & \multicolumn{2}{|c|}{ Annual } & & \\
\hline & & BR & AR & BR & $\mathbf{A R}$ & BR & AR & BR & AR & BR & AR & BR & AR & & \\
\hline 1 & $\begin{array}{l}\text { Land preparation } \\
\text { and Nursery }\end{array}$ & 3 & 4 & 0 & 11 & 0 & 0 & 4 & 9 & 1 & 12 & 0 & 5 & 8 & 41 \\
\hline 2 & Flowering & 0 & 7 & 0 & 0 & 0 & 1 & 2 & 5 & 0 & 0 & 0 & 6 & 2 & 19 \\
\hline 3 & Maturity & 0 & 0 & 0 & 0 & 0 & 1 & 1 & 12 & 0 & 0 & 0 & 8 & 1 & 21 \\
\hline 4 & Whole season & 0 & 6 & 0 & 0 & 0 & 0 & 6 & 0 & 3 & 7 & 0 & 6 & 9 & 19 \\
\hline 5 & Total & 3 & 17 & $\mathbf{0}$ & 11 & $\mathbf{0}$ & 2 & 13 & 26 & 4 & 19 & 0 & 25 & 20 & 100 \\
\hline
\end{tabular}

Note: BR-Before rehabilitation; AR-Before rehabilitation; A-Total number of respondents involved in ground water market before rehabilitation; BTotal number of respondents involved in ground water market after rehabilitation. 
in cash or in kind. In case of cash, it is decided on the basis of ha/hr of irrigation. It is Rs. 75/ha/watering (each watering $6 \mathrm{hr} / \mathrm{ha}$ ) for paddy crop. The amount normally earned by sellers is approximately Rs. 2,250/ha/season. In case of kind, the payment is one third of the yield/ha/ season. Hence, 20 bags will be given to the water sellers. Then amount earned by sellers is Rs. 10,000/ha (each bag of paddy costs Rs. 500/-). The latter one is beneficial for the sellers, and so they make use of the buyer's critical situation and earn Rs. 10,000/ha just through selling their ground water. Local water market is not practised for annual crop since only well owning farmers are involved in sugarcane cultivation and they are satisfied with their own well yield. But still very few farmers owning wells with poor yield are the reliant of neighbouring wells in the last 3 months of crop growth. During this three months period, the need may be of 6 watering (15 hr/watering/ha) to achieve a normal crop yield of 100 tons/ha. So, the buyer has to pay Rs. 6,300/ha (Rs. $70 /-$ to purchase water for 90 hours). Payment in cash to buy water for sugarcane is the common practice in Pelasur. Availability of water resources, scale and quality of adoption of irrigated farming technologies, progress of rural electrification, quality of power supply and extent of land fragmentation are among the factors that seem to influence the pace of development of water market [2].

Few well owning farmers, who are involved in agriculture as well as working in the Government and private sectors, leave their land fallow especially during the summer season. However, they sell water for needy farmers of adjacent non-well owning farmers. Crop sharing contract system is prevailing in this village where the seller provides only water while the buyer provides land, labour, manure and other inputs and both of them share the crop yield. One interesting case seen in Pelasur is that few respondents cultivating sugarcane alone sell water to nearby non-well owning paddy cultivators and get back an average of 10 bags/ha/year for their household consumption. Each bag of $75 \mathrm{~kg}$ paddy gives $40 \mathrm{~kg}$ of rice. Hence, the total $400 \mathrm{~kg}$ of rice is sufficient for the whole year for a household comprise 6 members. Only one respondent owning diesel pump is selling water to his adjacent field for second season paddy crop during its maturity stage. It is informed that buyers pay Rs. 50/hr/ha and also arrange for the diesel. Hence, for 4 to 5 watering, the diesel pumpset owners can earn Rs. 2,500/ha/season. Even though the local water market is successfully carried out in Pelasur for increasing overall productivity, sometimes farmers will not charge for their relatives because it is a homogenous caste group village. The intensity of irrigation may vary greatly in areas irrigated through water markets. However, the productivity of water is high since the buyers can get water when they need. Opportunity to buy minimum quantities of water at crucial stages of moisture stress enables small holders to take an additional crop. Water selling by adjacent well owners can have remarkable beneficial impacts on the income of water buyers and the economy of the community as a whole [2].

The output confirms the result that a significant positive relationship exists between local ground water market buying and tank rehabilitation ( $\mathrm{r}=0.453$, $\mathrm{p}<0.05)$. Therefore local ground water market buying is associated with tank rehabilitation but less correlated. Minimum ground water market buying for annual crop is the reason behind least correlation. The observations related to local ground water market buying and tank rehabilitation, which were randomly assigned to ensure that responses are due to the tank rehabilitation and not due to other factors. Paired t-test technique was used to test the null hypothesis and compare the results to prove that there is a difference between local ground water market buying before and after tank rehabilitation. The analysis output reveals that there is a difference between local ground water market buying by the respondents in pre and post rehabilitation periods. Hence, it is concluded that tank rehabilitation significantly improves the local ground water market buying, $\mathrm{t}(101)=3.154$, $\mathrm{p}<0.05$. The output confirms the result that a significant positive relationship exists between local ground water market selling and tank rehabilitation $(\mathrm{r}=0.905, \mathrm{p}<0.05)$. Therefore local ground water market buying is associated with tank rehabilitation but highly correlated. Increased ground water market selling for annual crop is the reason behind high correlation.

The observations related to local ground water market selling and tank rehabilitation, which were randomly assigned to ensure that responses are due to the tank rehabilitation and not due to other factors. Paired t-test technique was used to test the null hypothesis and compare the results to prove that there is a difference between local ground water market selling before and after tank rehabilitation. The analysis output reveals that there is a difference between local ground water market selling by the respondents in pre and post rehabilitation periods. Tank rehabilitation significantly improves the local ground water market selling. Hence, it is concluded that tank rehabilitation significantly improves the local ground water market selling, t $(101)=2.282$, $\mathrm{p}<0.05$.

\section{Conclusions}

Village tanks occupy a significant position in irrigation and in the local ecosystem in low rainfall areas. They have been one of the most important resources for the rural communities in the Indian subcontinent where there is no perennial river of importance. The performance of tanks is coming down due to various reasons. Since the tank irrigated areas benefit the marginal cultivators the livelihood of these communities gets affected. Conserva- 
tion and the revival of local management of these tanks is therefore the urgent need of the hour to help the poor communities to come out of their deprivation and have a secure livelihood. Hence the better ground water recharge through tank rehabilitation helps both well owning farmers and non-well owning farmers (marginal farmers) for income generation through increased cultivated area and number of season crop cultivated. Therefore tank rehabilitation is associated with local ground water market buying and selling.

\section{References}

[1] G. S. Prasad, "Public Resources and Private Appropriation," Economic and Political Weekly, Vol. 37, January 2004, pp. 8-29.

[2] T. Shah, "Water Markets and Irrigation Development in India,” Indian Journal of Agricultural Economics, Vol. 46, No. 3, 1991, pp. 335-348.

[3] T. Shah and K. V. Raju, "Rajasthan minor irrigation tank rehabilitation project,” Socio Ecological and Organisational Assessment for Swedish International Development Agency, New Delhi, 1991.
[4] N. Pant, "Trends in Groundwater Irrigation in Eastern and Western Utter Pradesh,” Economic and Political Weekly, Vol. 39, July 2004, pp. 3463-3468.

[5] N. Pant, "Control of and Access to Groundwater in Uttar Pradesh,” Economic and Political Weekly, Vol. 40, No. 26, June 2005, pp. 2672-2679.

[6] N. K. Dubash, "Ecologically and Socially Embedded Exchange-Gujarat Model of Water Markets,” Economic and Political Weekly, Vol. 35, No. 16, April 2000, pp. 1376-1385.

[7] T. Shah and V. Ballabh, "Water Markets in North BiharSix Village Studies in Muzaffarpur District," Economic and Political Weekly, Vol. 32, No. 52, December 1997, pp. A183-A190.

[8] T. Shah, "Groundwater Markets and Irrigation Development,” Oxford University Press, New Delhi, 1993.

[9] T. Shah, "Transforming Groundwater Markets in the Powerful Instruments of Small Farmer Development: Lessons from the Punjab, Uttar Pradesh And Gujarat," Overseas Development Institute (ODI), 11d, 1985.

[10] M. D. Kumar, L. Singar and P. Rath, "Value of Groundwater-Case Studies in Banaskantha," Economic and Political Weekly, Vol. 39, No. 3, July 2004, pp. 3498-3503. 